\title{
Faktor yang berhubungan dengan perilaku konsumsi buah dan sayur siswa SMP di Denpasar
}

\author{
Bella Nadya Rachman*, I Gede Mustika, I. G. A Wita Kusumawati
}

\begin{abstract}
Background : Adolescence is the transition from child to adulthood. Adolescents usually change their lifestyle, includes consumption patterns, because it is influenced by peers' environment. Adolescents nutritional needs are relatively large because of rapid growth and development process. One of the nutrition problems among adolescents is the lack of fruit and vegetable consumption that is influenced by internal and external factors.

Objective : The purpose of this research was to know the relationship between attitude, nutrition knowledge, food preference, food availability, media exposure, and parents income with fruit and vegetable consumption behavior among SMPK 1 Harapan students.

Methods : This study used cross sectional design and was conducted on April-May 2017. Subjects of this study were 85 grade VIII students selected by using simple random sampling. Information on attitude, nutrition knowledge, food preference, food availability, media exposure, and parents' income were collected using questionnaire, while fruit and vegetables consumption behaviour were collected using semi quantitative food frequency questionnaire (SQ-FFQ).

Results : The results of this study showed that most subjects has good fruit and vegetables consumption behavior (71.8\%). There was a significant correlation between fruit and vegetables consumption behaviour with attitude $(p<0,01)$, nutrition knowledge $(p<0.01)$, food availability ( $p<0.01)$, media exposure $(p<0.01)$, and parents income $(p<0.01)$, but not related with food preference $(p=0.55)$.

Conclusion :This study indicated a significant relationship between attitude, nutritional knowledge, food availability, media exposure, and parents income with fruits and vegetables consumption behaviour.
\end{abstract}

Keywords : fruit consumption; vegetable consumption; adolescents

\begin{abstract}
ABSTRAK
Latar belakang : Masa remaja adalah masa peralihan dari anak-anak menuju dewasa. Remaja biasanya mengalami perubahan gaya hidup termasuk di dalamnya pola konsumsi karena dipengaruhi oleh lingkungan teman sebaya. Kebutuhan gizi remaja relatif besar karena pada masa remaja terjadi proses pertumbuhan dan perkembangan yang cepat. Salah satu masalah pada fase ini adalah kurangnya konsumsi buah dan sayur yang dipengaruhi oleh faktor internal dan eksternal.

Tujuan : Tujuan penelitian ini adalah untuk menganalisis hubungan sikap, pengetahuan gizi, preferensi makanan, ketersediaan makanan, keterpaparan media, pendapatan orang tua dengan perilaku konsumsi buah dan sayur siswa SMPK 1 Harapan Denpasar.

Metode : Penelitian ini menggunakan desain Cross sectional yang dilakukan pada bulan April-Mei 2017. Subjek penelitian terdiri dari 85 siswa kelas VIII yang dipilih dengan teknik simple random sampling. Data sikap, pengetahuan gizi, preferensi makanan, ketersediaan makanan, keterpaparan media, pendapatan orang tua diambil menggunakan kuisioner, sedangkan perilaku konsumsi buah dan sayur diukur menggunakan form $S Q-F F Q$.

Hasil : Sebagian besar subjek mempunyai perilaku konsumsi buah dan sayur dalam kategori baik yaitu 71,8\%. Terdapat hubungan yang signifikan antara perilaku konsumsi buah dan sayur dengan sikap ( $p<0,01)$, pengetahuan gizi ( $p<0,01)$, ketersediaan makanan $(p<0,01)$, keterpaparan media $(p<0,01)$, pendapatan orang tua $(p<0,01)$, tetapi tidak terdapat hubungan dengan preferensi makanan $(p=0,55)$.

Simpulan : Penelitian ini menunjukkan adanya hubungan yang signifikan antara sikap, pengetahuan gizi, ketersediaan, keterpaparan media, dan pendapatan orang tua terhadap perilaku konsumsi buah dan sayur.
\end{abstract}

Kata kunci : konsumsi buah; konsumsi sayur; remaja

\section{PENDAHULUAN}

Masa remaja merupakan masa peralihan dari anak-anak menuju dewasa. Terjadi banyak perubahan baik pada fisik, psikis, sosial, maupun kebutuhan gizi

Program Studi Ilmu Gizi, Fakultas Kesehatan, Sains, dan Teknologi, Universitas Dhyana Pura. Jalan Raya Padang Luwih, Tegaljaya, Dalung, Badung-Bali.

*Korespondensi: bellanadya07@gmail.com pada remaja. Pada remaja terjadi perubahan gaya hidup termasuk pola konsumsi karena dipengaruhi oleh lingkungan teman sebaya agar dapat diterima dalam sebuah kelompok. Usia remaja (10-18 tahun) adalah periode yang rentan dengan zat gizi tertentu karena pada masa ini terjadi peningkatan proses pertumbuhan dan perkembangan fisik. ${ }^{1}$

World Health Organization (WHO) menyebutkan bahwa kurangnya konsumsi buah dan sayur dapat menyebabkan penyakit degeneratif seperti 
obesitas, diabetes hipertensi, tekanan darah tinggi, dan kanker. Kematian dini dan kehidupan produktif yang hilang karena cacat, 28\% dari kematian di seluruh dunia disebabkan karena rendahnya konsumsi buah dan sayur. Selain itu, tidak cukup buah dan sayur diperkirakan menyebabkan sekitar $14 \%$ dari kematian akibat kanker pencernaan, sekitar $11 \%$ dari jantung dan sekitar 9\% kematian stroke. Rekomendasi kecukupan konsumsi buah untuk mencegah penyakit kronis adalah 400-600 gram per hari. ${ }^{2}$

Rekomendasi kecukupan konsumsi buah dan sayur di Indonesia terdapat dalam tumpeng gizi seimbang yang berisi anjuran untuk mengkonsumsi buah sebanyak dua sampai tiga porsi sehari dan sayuran sebanyak tiga sampai lima porsi sehari. Pentingnya konsumsi buah dan sayur masih kurang disadari oleh penduduk Indonesia khususnya pada remaja. Menurut Riset Kesehatan Dasar (Riskesdas), konsumsi buah dan sayur dikategorikan "kurang" apabila tidak sesuai dengan anjuran dalam tumpeng gizi seimbang. ${ }^{3}$ Proporsi kurang makan buah dan sayur ( $<$ lima porsi per minggu) pada penduduk usia 10 tahun ke atas di Bali mengalami peningkatan dari $96,5 \%$ pada tahun 2007 menjadi 97,5\% pada tahun 2013.,4 Di kota Denpasar, konsumsi buah dan sayur lima porsi atau lebih baru mencapai $0,5 \%$. Sementara itu, perilaku konsumsi buah dan sayur pada kelompok usia 10-14 tahun baru sebesar $1,2 \%$. Usia ini merupakan masa pertumbuhan dan perkembangan yang cepat serta masa yang rentan kekurangan gizi. Pada masa ini mereka sedang berada pada jenjang Sekolah Menengah Pertama (SMP).

Beberapa hasil penelitian menunjukkan konsumsi buah dan sayur yang masih kurang. Hasil penelitian di Pekanbaru menunjukkan konsumsi buah dan sayur pada siswa SMA Negeri 1 Pekanbaru kurang dari 200 gram per hari $(64,6 \%)$ dengan frekuensi kurang dari dua kali sehari. ${ }^{5}$ Penelitian yang dilakukan di kota Makassar pada mahasiswa obesitas menunjukkan bahwa 98,3\% jarang mengkonsumsi sayur, $80,7 \%$ mengkonsumsi sayur dalam porsi yang kurang, dan sebagian besar mengkonsumsi buah dalam frekuensi yang jarang. ${ }^{6}$ Beberapa penelitian lain di Jakarta juga menunjukkan hasil serupa dimana hanya $57,5 \%$ siswa SMPN 8 Depok yang memenuhi konsumsi buah dan sayur 400 gram per hari, sementara pada 68,9\% siswa SMP Negeri 226 Jakarta Selatan dan $82,4 \%$ siswa kelas VIII dan IX SMPN 127 Jakarta Barat mengkonsumsi buah dan sayur dalam kategori kurang. ${ }^{7,8,9}$

Berdasarkan data tersebut diketahui bahwa secara umum konsumsi buah dan sayur pada remaja masing kurang. Selain itu, proporsi kurang konsumsi sayur dan buah di Denpasar lebih tinggi dibanding di kota-kota lain. Faktor-faktor yang mempengaruhi konsumsi buah dan sayur di Denpasar penting untuk digali sehingga dapat dilakukan upaya perbaikan yang tepat. Oleh karena itu, penelitian ini bertujuan untuk menganalisis faktor yang berhubungan dengan perilaku konsumsi buah dan sayur pada masa remaja di Denpasar.

\section{BAHAN DAN METODE}

Desain penelitian ini adalah Cross sectional yang dilakukan di SMPK 1 Harapan Denpasar pada bulan April-Mei 2017. Populasi dalam penelitian ini adalah siswa SMPK 1 Harapan Denpasar kelas VIII yang berjumlah 576 orang. Teknik pengambilan sampel menggunakan simple random sampling dan diperoleh sampel sebanyak 85 orang. Identitas sampel diperoleh dengan wawancara menggunakan form identitas sampel yang berisi nama, jenis kelamin, usia, tanggal lahir, dan nomer telepon.

Data perilaku konsumsi buah dan sayur diperoleh dengan melakukan wawancara menggunakan form SQ-FFQ dan dianalisis menggunakan nutrisurvey. Data sikap, pengetahuan gizi, preferensi makanan, ketersediaan makanan, keterpaparan media, dan pendapatan orang tua diperoleh menggunakan kuisioner yang sebelumnya telah diuji validitas dan reliabilitasnya. Data dianalisis dengan menggunakan uji korelasi rank Spearman untuk mengetahui hubungan antar variabel.

\section{HASIL}

Berdasarkan hasil penelitian diperoleh 85 responden sesuai dengan kriteria yang telah ditetapkan. Adapun karakteristik responden diketahui sebagian besar responden berjenis kelamin perempuan $(70,6 \%)$ dan berusia 14 tahun (71,8\%). Sementara itu, responden yang berusia 15 tahun berjumlah 24 orang $(28,2 \%)$.

\section{Perilaku konsumsi buah dan sayur}

Konsumsi buah dan sayur dikategorikan kurang jika konsumsi buah dan sayur <400 gram per hari. Berdasarkan hasil wawancara diketahui bahwa ratarata konsumsi buah dan sayur responden yaitu 452 gram. Perilaku konsumsi buah dan sayur siswa SMPK 1 Harapan menunjukkan bahwa 61 orang $(71,8 \%)$ memiliki perilaku konsumsi buah dan sayur dalam kategori baik dan 24 orang $(28,2 \%)$ dalam kategori kurang baik. Berdasarkan distribusi perilaku konsumsi buah dan sayur menurut jenis kelamin diketahui bahwa lebih dari separuh responden perempuan memiliki perilaku konsumsi dengan kategori baik yaitu sebanyak 46 orang $(54,1 \%)$ dan 14 orang $(16,5 \%)$ memiliki kategori kurang baik. Sementara itu, responden lakilaki yang memiliki perilaku konsumsi buah dan sayur dalam kategori baik sebanyak 15 orang $(17,6 \%)$, dan 
yang memiliki kategori kurang baik sebanyak 10 orang $(11,8 \%)$.

\section{Faktor-faktor yang berhubungan dengan konsumsi buah dan sayur}

Berdasarkan Tabel 1 diketahui bahwa sebagian besar responden perempuan memiliki sikap yang baik terhadap konsumsi buah dan sayur yaitu sebanyak 52 orang $(86,2 \%)$. Sementara itu, responden laki-laki yang yang memiliki sikap dalam kategori baik hanya 16 orang $(64,0 \%)$, lebih rendah dibandingkan responden perempuan.

Sebagian besar responden mempunyai pengetahuan gizi dalam kategori baik. Berdasarkan Tabel 1, responden perempuan yang mempunyai pengetahuan gizi dalam kategori baik (90\%), lebih banyak dibandingkan pada responden laki-laki (68\%).

Preferensi makanan adalah suka atau tidaknya seseorang terhadap suatu makanan dipengaruhi oleh beberapa faktor antara lain rasa, tekstur, dan warna. Berdasarkan Tabel 1 diketahui bahwa mayoritas responden mempunyai preferensi makanan yang baik.
Responden perempuan yang memiliki preferensi baik terhadap buah dan sayur berjumlah 57 orang (95\%), tidak berbeda jauh dengan preferensi baik pada lakilaki yaitu sebanyak 23 orang (92\%).

Berdasarkan Tabel 1 diketahui bahwa ketersediaan makanan berupa buah dan sayur pada perempuan lebih baik dibandingkan pada laki-laki. Ketersediaan makanan kategori baik pada perempuan yaitu sebesar $56,7 \%$ dan pada laki-laki sebesar $40 \%$.

Keterpaparan media lebih banyak pada perempuan dibandingkan pada laki-laki. Dari Tabel 1 diketahui sebanyak $71,7 \%$ responden perempuan terpapar media dengan baik, sementara hanya $44 \%$ responden laki-laki yang terpapar media dengan baik.

Berdasarkan Tabel 1 diketahui bahwa lebih dari separuh responden mempunyai orang tua dengan pendapatan cukup. Perempuan yang memiliki orang tua dengan pendapatan cukup berjumlah 36 orang (60\%), sedangkan responden laki-laki yang memiliki orang tua dengan pendapatan cukup berjumlah 13 orang $(52 \%)$.

Tabel 1. Hasil analisis sikap, pengetahuan gizi, preferensi makanan, ketersediaan makanan, keterpaparan media, pendapatan orang tua terhadap perilaku konsumsi buah dan sayur

\begin{tabular}{|c|c|c|c|c|c|c|c|}
\hline \multirow{3}{*}{ Variabel } & \multirow{3}{*}{ Kategori } & \multicolumn{6}{|c|}{ Konsumsi Buah dan Sayur } \\
\hline & & \multicolumn{2}{|c|}{ Kurang Baik } & \multicolumn{2}{|c|}{ Baik } & \multicolumn{2}{|c|}{ Total } \\
\hline & & n & $\%$ & $\mathbf{n}$ & $\%$ & $\mathbf{n}$ & $\%$ \\
\hline \multicolumn{8}{|l|}{ Sikap } \\
\hline \multirow[t]{2}{*}{ Laki-laki } & Kurang Baik & 9 & 36,0 & 0 & 0,0 & 9 & 36,0 \\
\hline & Baik & 1 & 4,0 & 15 & 60,0 & 16 & 64,0 \\
\hline \multirow[t]{2}{*}{ Perempuan } & Kurang Baik & 6 & 10,0 & 2 & 3,3 & 8 & 13,3 \\
\hline & Baik & 8 & 13,3 & 44 & 73,3 & 52 & 86,7 \\
\hline \multicolumn{8}{|l|}{ Pengetahuan Gizi } \\
\hline \multirow[t]{2}{*}{ Laki-laki } & Kurang Baik & 7 & 28,0 & 1 & 4,0 & 8 & 32,0 \\
\hline & Baik & 3 & 12,0 & 14 & 56,0 & 17 & 68,0 \\
\hline \multirow[t]{2}{*}{ Perempuan } & Kurang Baik & 5 & 8,3 & 1 & 1,7 & 6 & 10,0 \\
\hline & Baik & 9 & 15,0 & 45 & 75,0 & 54 & 90,0 \\
\hline \multicolumn{8}{|l|}{ Preferensi Makanan } \\
\hline \multirow[t]{2}{*}{ Laki-laki } & Kurang Baik & 1 & 4,0 & 1 & 4,0 & 2 & 8,0 \\
\hline & Baik & 9 & 36,0 & 14 & 56,0 & 23 & 92,0 \\
\hline \multirow[t]{2}{*}{ Perempuan } & Kurang Baik & 1 & 1,7 & 2 & 3,3 & 3 & 5,0 \\
\hline & Baik & 13 & 21,7 & 44 & 73,3 & 57 & 95,0 \\
\hline \multicolumn{8}{|l|}{ Ketersediaan Makanan } \\
\hline \multirow[t]{2}{*}{ Laki-laki } & Kurang Baik & 9 & 36,0 & 6 & 24,0 & 15 & 60,0 \\
\hline & Baik & 1 & 4,0 & 9 & 36,0 & 10 & 40,0 \\
\hline \multirow[t]{2}{*}{ Perempuan } & Kurang Baik & 10 & 16,7 & 16 & 26,7 & 26 & 43,3 \\
\hline & Baik & 4 & 6,7 & 30 & 50,0 & 34 & 56,7 \\
\hline \multicolumn{8}{|l|}{ Keterpaparan Media } \\
\hline \multirow[t]{2}{*}{ Laki-laki } & Kurang Baik & 8 & 32,0 & 6 & 24,0 & 14 & 56,0 \\
\hline & Baik & 2 & 8,0 & 9 & 36,0 & 11 & 44,0 \\
\hline \multirow[t]{2}{*}{ Perempuan } & Kurang Baik & 7 & 11,7 & 10 & 16,7 & 17 & 28,3 \\
\hline & Baik & 7 & 11,7 & 36 & 60,0 & 43 & 71,7 \\
\hline \multicolumn{8}{|l|}{ Pendapatan Orang Tua } \\
\hline \multirow[t]{3}{*}{ Laki-laki } & Rendah & 8 & 32,0 & 1 & 4,0 & 9 & 36,0 \\
\hline & Cukup & 1 & 4,0 & 12 & 48,0 & 13 & 52,0 \\
\hline & Tinggi & 1 & 4,0 & 2 & 8,0 & 3 & 12,0 \\
\hline \multirow[t]{3}{*}{ Perempuan } & Rendah & 10 & 16,7 & 2 & 3,3 & 12 & 20,0 \\
\hline & Cukup & 4 & 6,7 & 32 & 53,3 & 36 & 60,0 \\
\hline & Tinggi & 0 & 0,0 & 12 & 20,0 & 12 & 20,0 \\
\hline
\end{tabular}


Hubungan sikap, pengetahuan gizi, preferensi makanan, ketersediaan makanan, keterpaparan media, pendapatan orang tua dengan perilaku konsumsi buah dan sayur

Hasil uji korelasi Spearman antara sikap, pengetahuan gizi, ketersediaan makanan, keterpaparan media, pendapatan orang tua dengan perilaku konsumsi buah dan sayur siswa SMPK 1 Harapan menunjukkan hubungan yang signifikan dengan $p<0,01$. Akan tetapi, tidak terdapat hubungan yang signifikan antara variabel preferensi makanan dengan perilaku konsumsi buah dan sayur $(\mathrm{p}=0,55)$.

\section{PEMBAHASAN}

\section{Hubungan Sikap terhadap Perilaku Konsumsi Buah dan Sayur}

Sikap merupakan suatu reaksi terhadap stimulus atau objek dalam hal ini terhadap perilaku konsumsi buah dan sayur. Pada remaja, makanan dapat dijadikan sebagai simbol penerimaan pertemanan dalam hubungan sosial. Sikap penentuan pemilihan makanan pada remaja yang sebagian besar waktunya sangat tergantung pada teman sebaya juga dipengaruhi hubungan dengan teman sebaya. ${ }^{8}$

Berdasarkan Tabel 1 diketahui responden lakilaki yang memiliki sikap yang baik terhadap perilaku konsumsi buah dan sayur berjumlah 16 orang (64\%). Sementara itu, responden perempuan yang memiliki sikap yang baik berjumlah 52 orang $(86,7 \%)$. Hasil uji korelasi Spearman antara variabel sikap terhadap perilaku konsumsi buah dan sayur siswa SMPK 1 Harapan diperoleh hasil bahwa $\mathrm{p}<0,01$ yang memiliki arti terdapat hubungan yang signifikan antara variabel sikap dengan perilaku konsumsi buah dan sayur. Hal tersebut menunjukan bahwa semakin baik sikap remaja tentang pemilihan buah dan sayur, maka perilaku konsumsi buah dan sayur pada remaja akan semakin baik. Penelitian sejenis menyebutkan bahwa terdapat hubungan yang signifikan antara sikap dengan kebiasaan konsumsi buah dan sayur pada orang dewasa di Malaysia. ${ }^{10}$

Beberapa penelitian juga menunjukkan bahwa terdapat hubungan yang signifikan antara sikap terhadap perilaku. Sebuah penelitian menyebutkan bahwa terdapat hubungan signifikan antara sikap terhadap perilaku konsumsi buah dan sayur pada siswa kelas VIII dan IX SMPN 127 Jakarta Barat. ${ }^{9}$ Selain itu, penelitian lain menyebutkan bahwa konsumsi buah dan sayur yang lebih banyak terdapat pada siswa yang memiliki sikap baik terhadap buah dan sayur. ${ }^{12}$ Lebih lanjut, penelitian lain juga menyebutkan bahwa sikap adalah evaluasi secara keseluruhan termasuk perasaan yang mempengaruhi perilaku konsumsi termasuk terhadap konsumsi buah dan sayur. ${ }^{13}$
Pemilihan jenis makanan pada remaja merupakan penentuan status sosial dalam kelompok tersebut. Dengan demikian sikap dalam pemilihan makanan yang terjadi pada usia remaja merupakan suatu simbol penerimaan seseorang dalam sebuah kelompok. Oleh karena itu, dapat disimpulkan bahwa sikap merupakan salah satu faktor yang dapat menentukan perilaku konsumsi buah dan sayur.

\section{Hubungan Pengetahuan Gizi terhadap Perilaku Konsumsi Buah dan Sayur}

Pengetahuan gizi adalah pemahaman seseorang tentang ilmu gizi, zat gizi, serta interaksi zat gizi terhadap status gizi dan kesehatan. Pengetahuan tentang makanan yang sehat menjadi faktor yang penting dalam pemilihan makanan karena merupakan salah satu faktor untuk perilaku makan yang sehat. Kurangnya pengetahuan tentang gizi akan menyebabkan seseorang salah memilih makanan sehingga akan menurunkan konsumsi makanan sehat dan berdampak pada masalah gizi. ${ }^{8}$

Berdasarkan Tabel 1 dapat dilihat bahwa responden laki-laki yang memiliki pengetahuan gizi yang baik terhadap perilaku konsumsi buah dan sayur berjumlah 17 orang (68\%). Sementara itu, responden sebagian besar responden perempuan memiliki pengetahuan gizi yang baik yaitu 54 orang $(90 \%)$. Hasil uji korelasi Spearman antara variabel pengetahuan gizi terhadap perilaku konsumsi buah dan sayur siswa SMPK 1 Harapan diperoleh hasil bahwa $p<0,01$ yang berarti terdapat hubungan yang signifikan antara variabel pengetahuan gizi dengan perilaku konsumsi buah dan sayur. Pengetahuan gizi dan perilaku konsumsi buah dan sayur mempunyai hubungan yang positif yang berarti bahwa semakin tinggi pengetahuan gizi remaja, maka akan semakin tinggi pula konsumsi buah dan sayur.

Hasil penelitian ini sejalan dengan penelitian lain yang menyebutkan bahwa terdapat hubungan yang signifikan antara pengetahuan gizi dengan perilaku konsumsi buah dan sayur. Pengetahuan tentang nilai gizi dapat mempengaruhi konsumsi buah dan sayur sesorang. ${ }^{14}$ Selain itu, terdapat penelitian yang menyebutkan bahwa terjadi peningkatan konsumsi buah dan sayur pada responden setelah mendapatkan intervensi mengenai manfaat konsumsi sumber zat gizi serat pada siswa di Depok. ${ }^{14}$ Hasil serupa juga didapatkan oleh penelitian lain yang menemukan bahwa frekuensi konsumsi buah dan sayur lebih besar terdapat pada mahasiswa gizi (63\%) dibandingkan dengan mahasiswa jurusan lain. ${ }^{16}$

Pendidikan mengenai gizi penting diketahui dalam mewujudkan perilaku memilih makanan sehat khususnya konsumsi buah dan sayur. Pengetahuan gizi merupakan modal utama sesorang dalam pemilihan makanan. Hal ini menunjukan bahwa semakin baik 
pengetahuan gizi seseorang, maka semakin baik pula perilaku konsumsi buah dan sayur orang tersebut.

Upaya peningkatan pengetahuan gizi sesorang dapat dilakukan melalui pemberian penyuluhan, melalui media massa, elektronik, buku, permainan, dan kerabatan dekat. Peningkatan pengetahuan gizi tentang konsumsi buah dan sayur pada remaja diharapkan dapat meningkatkan pengetahuan dan perilaku konsumsi buah dan sayur yang lebih baik. ${ }^{15}$

\section{Hubungan Preferensi Makanan terhadap Perilaku Konsumsi Buah dan Sayur}

Preferensi atau kesukaan terhadap makanan merupakan sikap seseorang untuk suka atau tidak suka terhadap makanan tertentu. Kesukaan terhadap makanan dianggap sebagai faktor penentu dalam mengkonsumsi makanan termasuk buah dan sayur. Suka atau tidaknya seseorang terhadap suatu makanan antara lain bergantung pada rasa, tekstur, tampilan, dan kebiasaan makan. Preferensi buah dan sayur memiliki hubungan secara langsung terhadap konsumsi buah dan sayur, baik di rumah maupun di sekolah. ${ }^{8}$

Berdasarkan Tabel 1 diketahui bahwa sebagian besar responden laki-laki memiliki preferensi makanan yang baik terhadap perilaku konsumsi buah dan sayur (92\%). Selain itu, responden perempuan juga memiliki preferensi makanan yang baik (95\%). Hasil korelasi Spearman antara variabel preferensi makanan dengan perilaku konsumsi buah dan sayur siswa SMPK 1 Harapan diperoleh hasil bahwa $\mathrm{p}=0,552$ yang berarti tidak terdapat hubungan yang signifikan antara variabel preferensi makanan dengan perilaku konsumsi buah dan sayur.

Hasil ini sejalan dengan penelitian yang menyebutkan bahwa tidak terdapat hubungan yang signifikan antara preferensi makanan dengan konsumsi buah dan sayur yang dilakukan pada siswa SMPN 8 Depok. $^{7}$ Penelitiannya memperoleh hasil bahwa responden yang menyukai buah dan sayur sebanyak $59,1 \%$ sedangkan responden yang tidak menyukai buah dan sayur sebanyak $47,8 \%$. Penelitian lain yang sejenis juga memperoleh hasil bahwa sebagian besar responden tidak menyukai buah dan sayur karena beranggapan bahwa buah dan sayur tidak memiliki rasa enak. ${ }^{9}$

Demikian juga halnya dengan penelitian menyebutkan bahwa tidak terdapat hubungan yang signifikan antara preferensi terhadap konsumsi buah dan sayur pada remaja SMP 1 Kesu di kabupaten Toraja Utara. ${ }^{16}$ Penelitian lain menyebutkan bahwa tidak ada hubungan yang signifikan antara preferensi terhadap perilaku konsumsi buah dan sayur pada siswa SMP Negeri 28 Jakarta dan SMP Negeri 1 Jakarta tahun 2013 karena kurangnya motivasi mengkonsumsi buah dan sayur. ${ }^{17}$
Preferensi merupakan kesukaan seseorang terhadap suatu makanan yang dapat dipengaruhi oleh banyak faktor seperti rasa, tekstur, dan tampilan. Faktor lain yang mempengaruhi preferensi seseorang terhadap buah dan sayur yaitu ketersediaan. Seseorang akan mengkonsumsi buah dan sayur yang tersedia di rumah maupun di sekolah. Jika ketersediaan buah dan sayur kurang, maka paparan seseorang terhadap buah dan sayur pun ikut berkurang sehingga akan mempengaruhi preferensi orang tersebut.

\section{Hubungan Ketersediaan Makanan terhadap Perilaku Konsumsi Buah dan Sayur}

Ketersediaan makanan dapat mempengaruhi pola konsumsi seseorang terhadap pemilihan makanan yang akan dikonsumsi. Jika ketersediaan terhadap suatu makanan rendah, kemampuan seseorang untuk mendapatkan makanan tersebut akan semakin sulit. Jenis makanan yang tersedia lebih banyak mempunyai peluang lebih besar untuk dikonsumsi.

Berdasarkan Tabel 1 dapat dilihat bahwa sebagian besar responden laki-laki memiliki ketersediaan buah dan sayur kurang baik yaitu sejumlah 15 orang (60\%). Sementara itu, responden perempuan yang memiliki ketersediaan buah dan sayur yang kurang baik berjumlah 26 orang (43,3\%). Hasil uji korelasi Spearman antara variabel ketersediaan makanan dengan perilaku konsumsi buah dan sayur siswa SMPK 1 Harapan diperoleh hasil bahwa $\mathrm{p}<0,01$ yang berarti terdapat hubungan yang signifikan. Hubungannya mempunyai korelasi positif yang menunjukan bahwa semakin tinggi ketersediaan buah dan sayur maka semakin tinggi pula konsumsi buah dan sayur seseorang.

Hasil ini sejalan dengan penelitian yang mengatakan bahwa ketersediaan buah di rumah berbanding lurus dengan peningkatan konsumsi buah responden. ${ }^{18}$ Selain itu, hasil penelitian lain menunjukkan bahwa terdapat hubungan bermakna antara ketersediaan buah dan sayur di rumah dengan tingkat konsumsi buah dan sayur anak berusia 11 tahun pada sembilan kota di Eropa. ${ }^{19}$ Penelitian lain yang dilakukan di Gedangan, Kabupaten Sidoarjo mendapatkan hasil bahwa terdapat hubungan signifikan antara ketersediaan ikan, sayur, dan buah dengan konsumsi ikan, sayur dan buah pada anak usia prasekolah. Ketersediaan makanan yang kurang di rumah tangga dipengaruhi oleh pendapatan orang tua yang kurang mencukupi. ${ }^{20}$

Penelitian sejenis yang dilakukan di Amerika menyebutkan bahwa terdapat hubungan yang signifikan antara ketersediaan buah dan sayur dengan konsumsi rata-rata nasional pada remaja. ${ }^{21}$ Demikian juga dalam penelitian oleh Chandrawati yang menyebutkan bahwa jika ketersediaan buah dan sayur kurang maka paparan buah dan sayur pada anak akan 
terbatas sehingga mengurangi preferensi anak terhadap buah dan sayur. ${ }^{22}$ Penelitian oleh Layade menyebutkan bahwa ketersediaan dan akses terhadap buah dan sayur bergantung pada musim sehingga dapat mempengaruhi konsumsi buah dan sayur. ${ }^{23}$

Ketersediaan buah dan sayur dapat mempengaruhui seseorang dalam mengkonsumsi buah dan sayur baik di rumah maupun di sekolah. Jika ketersediaan buah dan sayur kurang maka akan menyebabkan berkurangnya tingkat kesukaan terhadap buah dan sayur tersebut.

\section{Hubungan Keterpaparan Media terhadap Perilaku Konsumsi Buah dan Sayur}

Keterpaparan media memiliki pengaruh besar terhadap perilaku konsumsi termasuk perilaku makan remaja. Salah satu keterpaparan media yang dapat mempengaruhi perilaku konsumsi makan khususnya buah dan sayur yaitu iklan. Selain menjadi media pemasaran, iklan juga juga memiliki peran penting sebagai sumber penyampaian informasi mengenai gizi.

Berdasarkan Tabel 1 diketahui bahwa lebih dari separuh responden laki-laki tidak terpapar oleh media, yaitu sebanyak 14 orang (56\%). Sementara itu, sebagian besar responden perempuan terpapar oleh media, yaitu sebanyak 43 orang $(71,7 \%)$. Hasil uji korelasi Spearman antara variabel keterpaparan media dengan perilaku konsumsi buah dan sayur siswa SMPK 1 Harapan diperoleh hasil bahwa $\mathrm{p}<0,01$ yang berarti terdapat hubungan yang signifikan anatara variabel keterpaparan media terhadap perilaku konsumsi buah dan sayur. Hal ini sejalan dengan hasil penelitian oleh Farisa yang mendapatkan hubungan yang signifikan antara keterpaparan media terhadap perilaku konsumsi buah dan sayur. Responden yang terpapar oleh media lebih banyak mengkonsumsi buah dan sayur $(60,1 \%)$ dibandingkan dengan responden yang tidak terpapar oleh media $(39,9 \%)^{7}$

Penelitian lain menyebutkan bahwa terdapat hubungan yang signifikan antara pengaruh edukasi gizi melalui media booklet dengan perilaku konsumsi buah dan sayur. ${ }^{24}$ Selain itu, penelitian lain yang dilakukan oleh Saputra menyebutkan bahwa terdapat pengaruh pemberian edukasi gizi melalui media video dan leaflet terhadap perubahan konsumsi buah dan sayur. Media mampu merangsang atau memasukkan informasi melalui berbagai indera, dimana semakin banyak indera yang dirangsang maka masuknya informasi akan semakin mudah. ${ }^{25}$

Pemberian edukasi gizi sangat dibutuhkan untuk anak-anak agar dapat membentuk sikap positif terutama dalam pemilihan makanan. Pengaruh penggunaan media dan alat peraga dapat mempengaruhi penerimaan informasi tersebut. Informasi akan ditangkap menggunakan panca indera, sehingga semakin banyak panca indera yang digunakan untuk menangkap informasi semakin banyak pula informasi yang didapatkan.

\section{Hubungan Pendapatan Orang Tua terhadap Perilaku Konsumsi Buah dan Sayur}

Pemenuhan kebutuhan suatu keluarga bergantung pada pendapatan keluarga terutama pendapatan orang tua. Pendapatan merupakan faktor yang menentukan kualitas dan kuantitas makanan yang dikonsumsi. Semakin tinggi pendapatan maka semakin besar peluang untuk memilih makanan yang baik. Sejalan dengan perubahan pendapatan seseorang maka akan diikuti pula dengan perubahan dalam susunan makanan yang dikonsumsi. Seseorang dengan status ekonomi yang tinggi cenderung akan mengkonsumsi makanan dengan memperhatikan kandungan gizi.

Berdasarkan Tabel 1 diketahui bahwa responden laki-laki yang memiliki orang tua dengan pendapatan cukup berjumlah 13 orang (52\%). Sementara itu, perilaku konsumsi buah dan sayur yang baik pada responden laki-laki dengan pendapatan orang tua rendah berjumlah 1 orang (4\%). Sebagian besar responden perempuan memiliki orang tua dengan pendapatan cukup, yaitu sejumlah 36 orang $(60 \%)$. Sementara itu, perilaku konsumsi buah dan sayur yang baik pada responden perempuan dengan pendapatan orang tua rendah sebanyak 2 orang $(3,3 \%)$.

Hasil uji korelasi Spearman antara variabel pendapatan orang tua dengan perilaku konsumsi buah dan sayur siswa SMPK 1 Harapan diperoleh hasil bahwa $\mathrm{p}<0,01$ yang berarti bahwa terdapat hubungan yang signifikan. Hal ini sejalan dengan penelitian di Palu yang menyebutkan bahwa terdapat hubungan yang signifikan antara pendapatan orang tua terhadap perilaku makan pada remaja SMA. ${ }^{26}$ Keluarga dari kalangan ekonomi yang tinggi lebih mampu menyediakan makanan beranekaragam seperti daging, ikan dan buah-buahan dibandingkan dengan keluarga dari kalangan ekonomi rendah. Selain itu, penelitian oleh Suryani juga menyebutkan bahwa terdapat hubungan yang signifikan antara pendapatan keluarga dengan konsumsi buah dan sayur. ${ }^{27}$ Hal ini membuktikan bahwa tingkat pendapatan turut menentukan konsumsi buah dan sayur pada remaja. Pendapatan yang tinggi cenderung diikuti dengan tingginya jumlah dan jenis pangan yang dikonsumsi.

Pendapatan orang tua sangat mempengaruhi pemenuhan kebutuhan dalam sebuah keluarga. Semakin tinggi pendapatan orang tua semakin tinggi pula daya beli makanan khususnya buah dan sayur. Tingkat pendapatan keluarga yang tinggi akan cenderung diikuti dengan tingginya jumlah dan jenis makanan yang dikonsumsi. Tingkat pendapatan akan mencerminkan kemampuan daya beli bahan makanan di tingkat rumah tangga, sehingga konsumsi makanan khususnya buah dan sayur baik jumlah maupun 
mutunya dipengaruhi oleh faktor pendapatan orang tua. $^{27}$

\section{SIMPULAN}

Terdapat hubungan yang signifikan antara sikap, pengetahuan gizi, ketersediaan makanan, keterpaparan media, dan pendapatan orang tua dengan perilaku konsumsi buah dan sayur pada remaja, sedangkan preferensi makanan tidak berhubungan dengan perilaku konsumsi buah dan sayur.

\section{DAFTAR PUSTAKA}

1. Almatsier, S., Soetardjo, S. \& Soekatri, M. Gizi Seimbang Dalam Daur Kehidupan. 1 ed. Jakarta: Gramedia Pustaka; 2011.

2. WHO. Nutrition in Adolescence Issue and Challeges for The Health Sector: Geneva : WHO Press; 2005.

3. Badan Penelitian dan Pengembangan Kesehatan Kementerian Kesehatan RI. Riset Kesehatan Dasar. Jakarta: Kementerian Kesehatan RI; 2013.

4. Badan Penelitian dan Pengembangan Kesehatan Kementerian Kesehatan RI. Riset Kesehatan Dasar. Jakarta: Kementerian Kesehatan RI; 2007.

5. Gustiara I. Konsumsi Buah dan Sayur Pada Siswa SMA Negeri 1 Pekanbaru. Jurnal Precure. 2012; 1(1):50-55.

6. Irfan, Bahar B, Hendrayati. Pola Konsumsi Sayur, Buah, dan Aktivitas Sedentari Mahasiswa Obesitas di Universitas Hasanuddin. [Skripsi]. Makassar: Program Studi Ilmu Gizi Fakultas Kesehatan Masyarakat Universitas Hasanuddin; 2012.

7. Farisa S. Hubungan Sikap, Pengetahuan, Ketersediaan, dan Keterpaparan Media Massa dengan Konsumsi Buah dan Sayur pada Siswa SMPN 8 Depok. [Skripsi]. Depok: Program Studi Gizi Fakultas Kesehatan Masyarakat Universitas Indonesia; 2012.

8. Lestari AD. Faktor-faktor yang Behubungan dengan Perilaku Konsumsi Buah dan Sayur pada Siswa SMP Negei 226 Jakarta Selatan. [Skripsi]. Jakarta: Program Studi Kesehatan Masyarakat Fakultas Kedokteran dan Ilmu Kesehatan Universitas Islam Negeri Syarif Hidayatullah; 2012.

9. Nurlidyawati. Faktor-faktor yang Berhubungan dengan Perilaku Konsumsi Buah dan Sayur pada Siswa Kelas VIII dan IX SMP Negeri 127 Jakarta Barat Tahun 2015. [Skripsi]. Jakarta: Program Studi Kesehatan Masyarakat Fakultas Kedokteran dan Ilmu Kesehatan Universitas Islam Negeri Syarif Hidayatullah; 2015.
10. Khairunnisa IO, Ab Karim MS, Karim R, Adzhan N, Halim NA, Osman S. Factors Influencing Fruits and Vegetables Consumption Behaviour Among Adults in Malaysia. Journal of Agribusiness Marketing. 2012; 5:29-46.

11. Mandira F, Indrawani YM. Konsumsi Buah dan Sayur menurut Karakteristik Responden, Pengaruh Teman Sebaya, Ketersediaan, dan Keterpaparan Media Massa pada Siswa di SMA Negeri 115 Jakarta tahun 2013. [Skripsi]. Depok: Program Studi Gizi Fakultas Kesehatan Masyarakat Universitas Indonesia; 2013.

12. Di Noia J, Cullen KW. Fruit and Vegetable Attitudes, Norms, and Intakes in Low Income Youth. Health Educ Behav. 2015; 42(6): 775-782.

13. Banwat ME, Lar LA, Daboer J, Audu S, Lassa S. Knowledge and Intake of Fruit and Vegetables Consumption among Adults in an Urban Community in North Central Nigeria. The Nigerian Health Journal. 2012; 12(1): 12-15

14. Sartika RAD. Pengaruh Pendidikan Gizi terhadap Pengetahuan dan Perilaku Konsumsi Serat pada Siswa. Jurnal Ilmu Pendidikan. 2011; 17(4): 322330.

15. Hussein RAEH. Can Knowledge alone predict vegetable and fruit consumption among adolescents? A transtheoretical model perspective. Egyption Public Health Association. 2011; 86:95103.

16. Khatima H, Jafar N, Salam A. Hubungan Perilaku dan Preferensi dengan Konsumsi Sayut dan Buah Pada Remaja SMPN 1 Kesu di Kabupaten Toraja Utara. [Skripsi]. Makassar: Program Studi Ilmu Gizi Fakultas Kesehatan Masyarakat Universitas Hasanuddin; 2015.

17. Melinda K. Faktor-faktor yang Berhubungan dengan Konsumsi Buah dan Sayur pada Siswa di SMP Negeri 28 Jakarta dan SMP Negeri 1 Jakarta Tahun 2013. [Skripsi]. Depok: Program Studi Gizi Fakultas Kesehatan Masyarakat Universitas Indonesia; 2013.

18. Mohammad, A. Konsumsi Buah dan Sayur Anak Usia Sekolah Dasar di Bogor. J. Gizi Pangan. 2015; 10(1):71-76.

19. Bourdeaudhuji ID, Velde S, Brug J, Due P, Wind M, Sandvik C, Maes K, Wolf A, Rodrigo CP, Yngve A, Thorsdottir I, Rasmussen M, Elmadfa I, Franchini B, Klepp KI. Personal, social, and environmental predictors, of daily fruit and vegetable intake in 11 years old children in nine European countries. Eur J Clin Nutr. 2008; 62: 834-841.

20. Khurilin ML. Faktor-faktor yang Berhubungan dengan Konsumsi Ikan, Sayur, dan Buah pada Anak Usia Pra Sekolah di TK LPII, Desa 
Sawotratap, Kecamatan Gendangan, Kabupaten sidoarjo. e-journal boga. 2015;4(2):41-46.

21. Di Noia J, Contento IR. Fruit and Vegetable Availability Enables Adolescent Consumption that Exceeds National Average. 2010;30(6):396-402.

22. Chandrawati E, Wiarsih W, Sukihananto S. Ketersediaan Buah dan Sayur Dalam Keluarga Sebagai Strategi Intervensi Peningkatan Konsumsi Buah dan Sayur Anak Usia Prasekolah. Jurnal Care. 2014;2(3):31-40.

23. Layade AI. Fruit and Vegetable Consumption Among Students of Tertiary Institutions in Oyo State. Rjoas. 2014;6(30):3-8.

24. Amin M, Indriasari R, Arundhana I. Pengaruh Edukasi Gizi Melalui Media Gizi Booklet Terhadap Perubahan Konsumsi Sayur dan Buah. [Skripsi]. Makassar: Program Studi Ilmu Gizi Fakultas Kesehatan Masyarakat Universitas Hasanuddin; 2016.
25. Saputra MD, Wahyuni Y, Nuzrina M. Pengaruh Pemberian Edukasi Gizi Melalui Media Video dan Leaflet Terhadap Perubahan Konsumsi Buah dan Sayur pada Siswa SMP Al Chasanah Tahun 2016. [Skripsi]. Jakarta: Program Studi Ilmu Gizi Fakultas Ilmu-Ilmu Kesehatan Universitas Esa Unggul; 2016.

26. Rahman N, Dewi NU, Armawaty F. Faktor-Faktor yang berhubungan dengan Perilaku Makan pada Remaja SMA Negeri 1 Palu. Jurnal Preventif. 2016. 7(1):1-64.

27. Suryani N, Anwar R, Wardani HK. Hubungan Status Ekonomi dengan Konsumsi Buah, Sayur dan Pengetahuan Terhadap Status Gizi pada Siswa SMP di Perkotaan dan Pedesaan di Kotamadya Banjar Baru Tahun 2014. Jurnal Kesehatan Indonesia. 2015; 5(3):6-15. 